\title{
A high-fructose diet induces insulin resistance but not blood pressure changes in normotensive rats
}

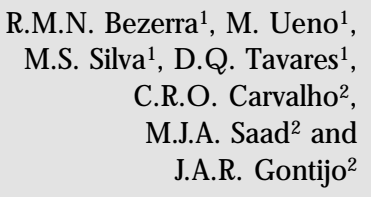

R.M.N. Bezerra' ${ }^{1}$, M. Ueno ${ }^{1}$, M.S. Silva ${ }^{1}$, D.Q. Tavares ${ }^{1}$, C.R.O. Carvalho, M.J.A. Saad ${ }^{2}$ and J.A.R. Gontijo ${ }^{2}$

\author{
1Departamento de Planejamento Alimentar e Nutrição, Faculdade de Economia e \\ Administração, Universidade Estadual de Campinas, Campinas, SP, Brasil \\ 2Departamento de Clínica Médica, Núcleo de Medicina e Cirurgia Experimental, \\ Faculdade de Ciências Médicas, Universidade Estadual de Campinas, \\ Campinas, SP, Brasil
}

\section{Correspondence}

J.A.R. Gontijo

Departamento de Clínica Médica

FCM, UNICAMP

13081-970 Campinas, SP

Brasil

Fax: + 55-19-788-8861

E-mail: gontijo@fcm.unicamp.br

Research supported by FAPESP, CNPq, PRONEX and CAPES.

Received September 21, 2000 Accepted June 1, 2001

\section{Abstract}

Rats fed a high-fructose diet represent an animal model for insulin resistance and hypertension. We recently showed that a high-fructose diet containing vegetable oil but a normal sodium/potassium ratio induced mild insulin resistance with decreased insulin receptor substrate-1 tyrosine phosphorylation in the liver and muscle of normal rats. In the present study, we examined the mean blood pressure, serum lipid levels and insulin sensitivity by estimating in vivo insulin activity using the 15-min intravenous insulin tolerance test (ITT, $0.5 \mathrm{ml}$ of $6 \mu \mathrm{g}$ insulin, $i v$ ) followed by calculation of the rate constant for plasma glucose disappearance $\left(K_{\text {itt }}\right)$ in male Wistar-Hannover rats $(110-130 \mathrm{~g})$ randomly divided into four diet groups: control, 1:3 sodium/potassium ratio $\left(\mathrm{R}_{\mathrm{Na}: \mathrm{K}}\right)$ diet (C 1:3 $\left.\mathrm{R}_{\mathrm{Na}: \mathrm{K}}\right)$; control, 1:1 sodium/potassium ratio diet $\left(\mathrm{CNa}\right.$ 1:1 $\left.\mathrm{R}_{\mathrm{Na}} \mathrm{K}\right)$; high-fructose, 1:3 sodium/potassium ratio $\operatorname{diet}\left(\mathrm{F} 1: 3 \mathrm{R}_{\mathrm{Na}: \mathrm{K}}\right.$ ), and high-fructose, 1:1 sodium/potassium ratio diet (FNa 1:1 $R_{N a: K}$ ) for 28 days. The change in $R_{N a: K}$ for the control and high-fructose diets had no effect on insulin sensitivity measured by ITT. In contrast, the $1: 1 \mathrm{R}_{\mathrm{Na}: \mathrm{K}}$ increased blood pressure in rats receiving the control and high-fructose diets from $117 \pm 3$ and $118 \pm 3 \mathrm{mmHg}$ to $141 \pm 4$ and $132 \pm 4 \mathrm{mmHg}(\mathrm{P}<0.05)$, respectively. Triacylglycerol levels were higher in both groups treated with a high-fructose diet when compared to controls $\left(\mathrm{C} 1: 3 \mathrm{R}_{\mathrm{Na}: \mathrm{K}}\right.$ : $1.2 \pm 0.1 \mathrm{mmol} / \mathrm{l}$ vs $\mathrm{F} 1: 3$ $\mathrm{R}_{\mathrm{Na}: \mathrm{K}}: 2.3 \pm 0.4 \mathrm{mmol} / \mathrm{l}$ and $\mathrm{CNa} 1: 1 \mathrm{R}_{\mathrm{Na}: \mathrm{K}}: 1.2 \pm 0.2 \mathrm{mmol} / \mathrm{l}$ ws $\mathrm{FNa} 1: 1$ $\left.\mathrm{R}_{\mathrm{Na}: \mathrm{K}}: 2.6 \pm 0.4 \mathrm{mmol} / \mathrm{l}, \mathrm{P}<0.05\right)$. These data suggest that fructose alone does not induce hyperinsulinemia or hypertension in rats fed a normal $\mathrm{R}_{\mathrm{Na}: \mathrm{K}}$ diet, whereas an elevation of sodium in the diet may contribute to the elevated blood pressure in this animal model.

\section{Key words}

- High-fructose diet

- Insulin resistance

- Blood pressure

- Hypertriglyceridemia

- Plasma cholesterol

\section{Introduction}

There is considerable evidence suggesting that changes in glucose and insulin metabolism may play a role in the etiopathogenesis of high arterial blood pressure (1-3). Insulin resistance, hyperinsulinemia, hyper- triglyceridemia and high blood pressure can be induced in fructose-fed rats (4-6). However, the precise mechanism by which hypertension develops in these animals has not been identified $(2,3,7)$. We recently showed that a high-fructose diet alters the early steps of insulin action (7), and may therefore play 
a role in the insulin resistance observed in animals fed this diet.

High-fructose diets are heterogeneous in composition since they include a certain amount of animal lard and since variable amounts of sodium and potassium are present in experimental and control diets $(4,8,9)$. Epidemiological evidence suggests that low potassium intake is associated with the probability of the occurrence of hypertension and stroke. Sodium/potassium ratio $\left(\mathrm{R}_{\mathrm{Na}: \mathrm{K}}\right)$ interaction must be concomitantly considered in the investigation of the association of either of these cations with hypertension and cardiovascular disease (10). In the present study, we examined the influence of a change in the sodium/potassium ratio of the highfructose diet on insulin sensitivity, mean arterial pressure and serum triacylglycerol and cholesterol levels in Wistar rats.

\section{Material and Methods}

\section{Experimental design}

Five-week-old male Wistar-Hannover rats (110-130 g) bred at the animal facilities of the State University of Campinas were randomly divided into four diet groups: control, 1:3 sodium/potassium ratio diet $\left(\mathrm{C} 1: 3 \mathrm{R}_{\mathrm{Na}: \mathrm{K}}\right)$; control, $1: 1$ sodium/potassium ratio diet $(\mathrm{CNa}$ $1: 1 \mathrm{R}_{\mathrm{Na}: \mathrm{K}}$ ); high-fructose, 1:3 sodium/potassium ratio diet (F 1:3 $\left.\mathrm{R}_{\mathrm{Na:K}}\right)$, and high-fructose, 1:1 sodium/potassium ratio diet (FNa 1:1 $\mathrm{R}_{\mathrm{Na}: \mathrm{K}}$ ) for the next 28 days. The general guidelines established by the Declaration of Helsinki (1964) for laboratory animals were followed throughout the study. The C 1:3 $\mathrm{R}_{\mathrm{Na}: \mathrm{K}}$ diet was standard rodent chow (Nuvilab-Nuvital, Curitiba, PR, Brazil) containing vegetable starch $(527 \mathrm{~g} / \mathrm{kg}$ diet $)$, fat as vegetable oil (35 g/kg diet), animal protein $\left(220 \mathrm{~g} / \mathrm{kg}\right.$ diet), and 1:3.3 $\mathrm{R}_{\mathrm{Na}: \mathrm{K}}\left(3 \mathrm{~g} \mathrm{Na}^{+} /\right.$ $\mathrm{kg}$ diet and $10 \mathrm{~g} \mathrm{~K}^{+} / \mathrm{kg}$ diet). The CNa 1:1 $\mathrm{R}_{\mathrm{Na}: \mathrm{K}}$ diet was the same as the standard rodent chow except that it contained the 1:1 $\mathrm{R}_{\mathrm{Na}: \mathrm{K}}\left(10 \mathrm{~g} \mathrm{Na}^{+} / \mathrm{kg}\right.$ diet and $10 \mathrm{~g} \mathrm{~K}^{+} / \mathrm{kg}$ diet $)$ by the addition of sodium salt. The $\mathrm{F} 1: 3$ $\mathrm{R}_{\mathrm{Na}: \mathrm{K}}$ diet contained fructose $(624 \mathrm{~g} / \mathrm{kg}$ diet $)$, fat as vegetable oil $(50 \mathrm{~g} / \mathrm{kg}$ diet $)$, protein (223 $\mathrm{g} / \mathrm{kg}$ diet), and 1:3.6 sodium/potassium ratio. The FNa 1:1 $\mathrm{R}_{\mathrm{Na:K}}$ diet was the same as the high-fructose diet except that it contained the 1:1 sodium/potassium ratio by the addition of sodium salt. The fiber, mineral and vitamin mix used in the experimental diets met the recommendation specified in AIN-93 (11). The rats had free access to food and tap water, were maintained under standard conditions $\left(20-22^{\circ} \mathrm{C}\right.$ and a 12-h light/ dark cycle) and were weighed weekly.

\section{Fifteen-minute insulin tolerance test}

After 28 days of treatment, the rats were fasted overnight and submitted to an intravenous insulin tolerance test (ITT; $0.5 \mathrm{ml}$ of 6 $\mu \mathrm{g}$ insulin, $i v$ ) and samples for blood glucose determination were collected at 0 (basal), 4 , 8,12 , and 16 min after injection. Rats were anesthetized with thiopental $(60 \mathrm{mg} / \mathrm{kg}$ body weight, ip), $40 \mu \mathrm{l}$ of blood was collected from their tail, and blood glucose level was measured by the glucose oxidase method. Thereafter, the rate constant for plasma glucose disappearance $\left(K_{\mathrm{itt}}\right)$ was calculated using the formula $0.693 / t_{1 / 2}$. The plasma glucose $t_{1 / 2}$ was calculated from the slope of the least squares analysis of the plasma glucose concentrations during the linear phase of decline (12).

\section{Biochemical measurements}

During the postabsorptive states, the rats were anesthetized with thiopental $(60 \mathrm{mg} / \mathrm{kg}$ body weight, ip) after a 5-h fast, and blood samples were drawn by cardiac puncture. After centrifugation, the sera were aliquoted and frozen until assayed for triacylglycerol and cholesterol concentrations by an enzymatic method using a commercial kit (Labtest, Campinas, SP, Brazil), and for insulin concentrations by a double-antibody radioim- 
munoassay (Diagnostic Products Corp., Los Angeles, CA, USA). Samples collected in the basal state prior to the ITT were used to determine plasma glucose concentration by an enzymatic method (Labtest).

\section{Blood pressure measurement}

Twenty-six days after starting the standard and special diets, a tail-cuff system (MKIV, Narco BioSystems, Austin, TX, USA) combining a transducer/amplifier which provides output signals proportional to cuff pressure and amplified Korotkoff sounds was used to obtain blood pressure measurements in conscious rats. This indirect approach permits repeated measurements with a close correlation (correlation coefficient $=0.975)$ compared to direct intra-arterial recording (13).

\section{Statistical analysis}

The results are reported as means \pm SEM. Statistical analysis of the data was performed using a two-factor analysis of variance (ANOVA) with repeated measures followed by the Newman-Keuls post hoc test. A $\mathrm{P}$ value $<0.05$ was considered to indicate significance.

\section{Results}

Despite the similarity in body weight gain, serum triacylglycerol and total cholesterol levels were different among groups. Triacylglycerol levels were higher in both groups treated with the high-fructose (F 1:3 $\mathrm{R}_{\mathrm{Na}: \mathrm{K}}$ and FNa 1:1 $\left.\mathrm{R}_{\mathrm{Na:K}}\right)$ diets when compared to the control (C 1:3 $\mathrm{R}_{\mathrm{Na}: \mathrm{K}}$ and $\mathrm{CNa}$ 1:1 $\mathrm{R}_{\mathrm{Na}: \mathrm{K}}$ diets, respectively) (C 1:3 $\mathrm{R}_{\mathrm{Na}: \mathrm{K}}: 1.2 \pm 0.1$ $\mathrm{mmol} / \mathrm{l}$ vs $\mathrm{F} 1: 3 \mathrm{R}_{\mathrm{Na}: \mathrm{K}}: 2.3 \pm 0.4 \mathrm{mmol} / \mathrm{l}$ and CNa 1:1 $\mathrm{R}_{\mathrm{Na}: \mathrm{K}}: 1.2 \pm 0.2 \mathrm{mmol} / \mathrm{l}$ vs FNa $1: 1$ $\left.\mathrm{R}_{\mathrm{Na}: \mathrm{K}}: 2.6 \pm 0.4 \mathrm{mmol} / \mathrm{l}, \mathrm{P}<0.05\right)$. The change in the sodium/potassium ratio $\left(1: 1 \mathrm{R}_{\mathrm{Na}: \mathrm{K}}\right)$ in the high-fructose diet induced a significant increase in plasma cholesterol levels from
$1.9 \pm 0.1$ to $2.2 \pm 0.1 \mathrm{mmol} / \mathrm{l}$ compared to the standard sodium/potassium ratio $\left(1: 3 \mathrm{R}_{\mathrm{Na}: \mathrm{K}}\right)$ high-fructose diet (Table 1).

To evaluate the effect of a high-fructose diet on insulin sensitivity, rats from the four groups underwent a 15-min ITT. The glucose disappearance rate $\left(K_{\text {itt }}\right)$ was significantly lower in fructose-fed and 1:1 sodium/ potassium ratio fructose-fed rats compared to control rats $\left(\mathrm{C} 1: 3 \mathrm{R}_{\mathrm{Na:K}}: 4.3 \pm 0.3\right.$ vs $\mathrm{F} 1: 3$ $\mathrm{R}_{\mathrm{Na}: \mathrm{K}}: 2.9 \pm 0.2 \% / \mathrm{min}$, and C $1: 3 \mathrm{R}_{\mathrm{Na}: \mathrm{K}}: 4.3 \pm$ 0.3 vs FNa $\left.1: 1 \mathrm{R}_{\mathrm{Na}: \mathrm{K}}: 3.0 \pm 0.2 \% / \mathrm{min}, \mathrm{P}<0.05\right)$ (Table 1). There was no significant difference in serum insulin between the highfructose and control groups.

The blood pressures of the four groups of rats are shown in Table 1. An increase in blood pressure occurred only in the changed sodium/potassium ratio diet groups (C 1:3 $\mathrm{R}_{\mathrm{Na}: \mathrm{K}}: 117 \pm 3 \mathrm{mmHg}$ vs $\mathrm{CNa} 1: 1 \mathrm{R}_{\mathrm{Na}: \mathrm{K}}: 141$ $\pm 4 \mathrm{mmHg}$, and F 1:3 $\mathrm{R}_{\mathrm{Na}: \mathrm{K}}: 118 \pm 3 \mathrm{mmHg}$ vs FNa 1:1 $\left.\mathrm{R}_{\mathrm{Na}: \mathrm{K}}: 132 \pm 4 \mathrm{mmHg}, \mathrm{P}<0.05\right)$.

Table 1. Body weight, blood pressure, and serum glucose, insulin, triacylglycerol and cholesterol levels in rats randomly divided into four diet groups: control, 1:3 sodium/ potassium ratio diet (C 1:3 $\mathrm{R}_{\mathrm{Na}} \mathrm{K}$ ); control, 1:1 sodium/potassium ratio diet (CNa 1:1 $\mathrm{R}_{\mathrm{Na}}$ K); high-fructose, 1:3 sodium/potassium ratio diet (F 1:3 $\mathrm{R}_{\mathrm{Na}} \mathrm{K}$ ), and high-fructose, 1:1 sodium/potassium ratio diet (FNa 1:1 $\mathrm{R}_{\mathrm{Na}} \mathrm{K}$ ) for the next 28 days.

\begin{tabular}{|c|c|c|c|c|}
\hline & C 1:3 R $\mathrm{Na:K}_{\mathrm{K}}$ & CNa 1:1 R $\mathrm{R}_{\mathrm{Na}} \mathrm{K}$ & F 1:3 $\mathrm{R}_{\mathrm{Na}: \mathrm{K}}$ & FNa 1:1 R $\mathrm{R}_{\mathrm{Na}} \mathrm{K}$ \\
\hline Body weight (g) & $\begin{array}{c}288 \pm 7 \\
(18)\end{array}$ & $\begin{array}{c}292 \pm 5 \\
(16)\end{array}$ & $\begin{array}{c}277 \pm 4 \\
(16)\end{array}$ & $\begin{array}{c}278 \pm 5 \\
(17)\end{array}$ \\
\hline Tail blood pressure $(\mathrm{mmHg})$ & $\begin{array}{c}117 \pm 3 \\
(12)\end{array}$ & $\begin{array}{c}141 \pm 4^{*} \\
(12)\end{array}$ & $\begin{array}{c}118 \pm 3 \\
(12)\end{array}$ & $\begin{array}{c}132 \pm 4^{+} \\
(12)\end{array}$ \\
\hline $\mathrm{K}_{\text {itt }}(\% / \mathrm{min})$ & $\begin{array}{c}4.3 \pm 0.3 \\
(14)\end{array}$ & $\begin{array}{c}3.5 \pm 0.3 \\
\text { (8) }\end{array}$ & $\begin{array}{c}2.9 \pm 0.3^{\#} \\
(13)\end{array}$ & $\begin{array}{l}3.0 \pm 0.2^{+} \\
(14)\end{array}$ \\
\hline Basal glucose (mmol/l) & $\begin{array}{c}4.7 \pm 0.3 \\
(15)\end{array}$ & $\begin{array}{c}5.2 \pm 0.2 \\
\text { (8) }\end{array}$ & $\begin{array}{c}4.9 \pm 0.3 \\
(15)\end{array}$ & $\begin{array}{c}4.7 \pm 0.9 \\
(16)\end{array}$ \\
\hline Insulin (pmol/l) & $\begin{array}{c}266 \pm 26 \\
\text { (7) }\end{array}$ & $\begin{array}{c}253 \pm 10 \\
(6)\end{array}$ & $\begin{array}{c}266 \pm 18 \\
\text { (7) }\end{array}$ & $\begin{array}{c}266 \pm 16 \\
\text { (7) }\end{array}$ \\
\hline Cholesterol (mmol/l) & $\begin{array}{c}1.6 \pm 0.1 \\
(9)\end{array}$ & $\begin{array}{c}1.7 \pm 0.1 \\
(8)\end{array}$ & $\begin{array}{c}1.9 \pm 0.1 \\
\text { (9) }\end{array}$ & $\begin{array}{c}2.2 \pm 0.1^{+, \#} \\
\text { (7) }\end{array}$ \\
\hline Triacylglycerol (mmol/l) & $\begin{array}{c}1.2 \pm 0.1 \\
\text { (8) }\end{array}$ & $\begin{array}{c}1.2 \pm 0.2 \\
\text { (8) }\end{array}$ & $\begin{array}{c}2.3 \pm 0.4^{\#} \\
(8)\end{array}$ & $\begin{array}{c}2.6 \pm 0.4^{+} \\
(8)\end{array}$ \\
\hline
\end{tabular}

$\mathrm{P}<0.05:{ }^{*} \mathrm{C} 1: 3$ vs $\mathrm{CNa} 1: 1,+\mathrm{F} 1: 3$ vs $\mathrm{FNa} 1: 1$, and ${ }^{\#} \mathrm{C} 1: 3$ vs $\mathrm{F} 1: 3$ or $\mathrm{F} 1: 1$ (ANOVA followed by the Newman-Keuls post hoc test).

Basal glucose levels were determined at 8 am after an ovemight fast. Insulin, triacylglycerol and cholesterol levels were measured in the postabsorptive state $(2 \mathrm{pm})$. The results are reported as the means \pm SEM of the number of rats indicated in parentheses. $\mathrm{K}_{\text {itt }}=$ rate constant for plasma glucose disappearance. 
There was no significant difference in blood pressure levels between the high-fructose and control groups, indicating that the ingestion of fructose alone was not sufficient to cause an increase in arterial blood pressure in this model.

\section{Discussion}

Hypertriglyceridemia, hyperinsulinemia and hypertension are common features of animal models of insulin resistance induced by a high-fructose diet $(4-6,8,9,14)$. As shown above, fructose-induced hypertension in rats was related to the changes in the sodium/ potassium ratio used in the high-fructose diet, whereas hypertriglyceridemia was present regardless of the blood pressure level $(4,6,8,9)$. Hypertriglyceridemia may be secondary to increases in the very low-density lipoprotein-triglyceride (VLDL-TG) secretion rate since elevations in plasma triacylglycerol levels have been correlated with rises in this rate $(8,14,15)$. Previous studies have shown that the VLDL-TG secretion rate in the liver of rats fed a high-sucrose lard or high-fructose lard diet was higher than that of controls $(8,14,15)$. Insulin resistance may contribute to hypertriglyceridemia by reducing the inhibitory effect of insulin on VLDL-TG secretion $(15,16)$. Recent studies have shown that the insulin resistance induced by a high-fructose diet was overcome completely by treatment with the hypolipidemic agents benfluorex and bezafibrate which restored normal triacylglycerol concentrations $(16,17)$.

Although the effects of a high-fructose diet on plasma triacylglycerol levels are often substantial, the response of plasma cholesterol to a fructose-containing diet is not clear. An increase in VLDL synthesis, which contains $10-20 \%$ cholesterol and transports triacylglycerol produced in the liver, may account for the increase in plasma cholesterol levels after the consumption of a fructose-containing diet (18-20). Reiser (21) re- ported that in two out of 14 animal studies there was an increase in plasma cholesterol levels after feeding fructose diets. In the present study, the high-fructose group had plasma cholesterol levels similar to the control group. However, when the sodium/potassium ratio was changed in the highfructose diet, the plasma cholesterol concentration rose significantly. Although several reports suggest that intestinal fructose transport occurs by a carrier-mediated mechanism and is $\mathrm{Na}^{+}$-independent (18), other studies indicate that in the small intestine fructose accumulates against a concentration gradient by an energy- and $\mathrm{Na}^{+}$-dependent process $(19,20)$. The changes in the sodium/ potassium ratio increased the sodium content of the high-fructose diet, a fact that may favor the increased fructose absorption in the small intestine, thus supplying more fructose to the liver.

Although there was no change in serum insulin level, the high-fructose-fed rats showed a reduced glucose disappearance rate in the 15-min ITT, confirming the lower insulin sensitivity of these rats. The insulin resistance in this animal model probably results from the impairment of insulin-stimulated glucose uptake in insulin-responsive tissues as well as changes in hepatic glucose metabolism. Using the hyperinsulinemic euglycemic clamp, fructose-fed rats were shown to have an impaired ability to suppress hepatic glucose production and to eliminate peripheral glucose (22). An increase in the gluconeogenic enzymes glucose-6-phosphatase and phosphoenolpyruvate carboxykinase has been reported for the liver of fructose-fed rats (22-27). Furthermore, a high-fructose diet was reported to reduce hepatic glycogen synthesis $(24,27)$. Insulin may regulate the activities of these enzymes through proteins activated downstream to the insulin receptor (24-26). We recently showed that fructose-induced insulin resistance was associated with a slight decrease in insulin receptor substrate-1 phosphoryla- 
tion and insulin receptor substrate- $1 /$ phosphoinositol 3-kinase association in the liver and muscle of intact rats (7). These observations support the hypothesis that fructose produces changes in steps beyond the receptor and may be involved in the insulin resistance observed in this animal model.

However, although the high-fructose diet in the present study induced insulin resistance, there were no changes in serum insulin concentrations. This observation has important implications for our understanding of the association between insulin resistance and hypertension, and suggests the following hypothetical model to link the two phenomena. The balance between pressor and depressor forces sets the vascular tone. Since insulin acts as a vasodepressor, its inability to decrease blood pressure and vascular resistance in insulin-resistant models would effectively tip the balance in favor of pressor forces. Thus, in this situation, insulin resistance rather than hyperinsulinemia acts as a risk factor for the development of hypertension. However, it is important to emphasize that the fat source normally used in most previous studies was lard, whereas in the present study we used as fat source vegetable oil similar to control diet. It is possible that the effects of lard and fructose are synergistic in altering the insulin levels of rats fed a high-fructose diet.

The precise mechanism by which hypertension develops in fructose-fed rats has not yet been elucidated, although an increase in sympathetic activity could be involved (4). Furthermore, circulating catecholamines are elevated in sucrose-fed rats on a high-salt diet, and it has been proposed that these mediators may contribute to hypertension through their vasoconstrictive and/or antinatriuretic properties (28-30). However, catecholamines are probably not the only vasoconstrictive factors involved in the development of hypertension in fructose-fed rats. The role of the renin-angiotensin system in the pathogenesis of fructose-induced hyper- tension is not well known. Previous studies have shown a normal plasma renin activity in this experimental model (9). On the other hand, the $\mathrm{AT}_{1}$ receptor antagonist losartan and an angiotensin-converting enzyme inhibitor attenuated the magnitude of the blood pressure elevation and improved insulin sensitivity in fructose-fed rats (28-30). Although several reports indicate fructose as a factor involved in hypertension $(4,5,9)$, several investigators have failed to observe an increase in blood pressure in fructose-fed rats $(31,32)$. These apparently conflicting data have been attributed to differences in the composition of the diets and to variable blood pressure responses to fructose among different ages and strains of normotensive rats $(31,32)$. We observed no significant difference in blood pressure between the highfructose and control groups. In addition, changing the sodium/potassium ratio of the control and high-fructose diets significantly increased the blood pressure in both groups. Using high fructose and high-fructose lard diets, Matsui et al. (17) observed that the systolic blood pressure was significantly higher in the high-fructose lard group than in the high-fructose and control groups.

Our results confirm previous observations that hypertriglyceridemia develops when rats consume a high-fructose diet. However, a high-fructose diet alone does not induce hyperinsulinemia and hypertension when the sodium/potassium ratio is normal. Thus, the presence of saturated fat and above normal sodium levels in the diet can affect the insulin concentrations and blood pressure levels in this animal model.

\section{Acknowledgments}

The authors thank Vêpe Indústria Alimentícia Ltda. (São Bernardo do Campo, SP, Brazil) for kindly providing the fructose, and Mr. L. Janeri and Ms. C. da Silva for technical assistance. 


\section{References}

1. Reaven GM (1990). Role of abnormalities of carbohydrate and lipoprotein metabolism in the pathogenesis and clinical course of hypertension. J ournal of Cardiovascular Pharmacology, 15 (Suppl 5): S4S7.

2. Defronzo RA \& Ferrannini E (1991). Insulin resistance: a multifaceted syndrome responsible for NIDDM, obesity, hypertension, dyslipidemia, and atherosclerotic cardiovascular disease. Diabetes Care, 14: 173-194.

3. Muscelli EO, Saad MJ \& Gontijo JAR (1991). Insulinemia and blood pressure responses to oral glucose load in primary hypertensive patients. Cardiology, 79: 1419.

4. Hwang I-S, Ho H, Hoffman BB \& Reaven GM (1987). Fructose-induced insulin resistance and hypertension in rats. Hypertension, 10: 512-516.

5. Reaven GM, Ho H \& Hoffmann BB (1989). Somatostatin inhibition of fructose-induced hypertension. Hypertension, 14: 117-120.

6. Huang Y-J, Fang VS, J uan C-C, Chou Y-C, Kwok C-F \& Ho L-T (1997). Amelioration of insulin resistance and hypertension in a fructose-fed rat model with fish oil supplementation. Metabolism, 46: 1252 1258.

7. Bezerra RM, Ueno M, Silva MS, Tavares DQ, Carvalho CR \& Saad MJ (2000). A high fructose diet affects the early steps of insulin action in muscle and liver of rats. J oumal of Nutrition, 130: 1531-1535.

8. Zavaroni I, Chen Y-DI \& Reaven GM (1982). Studies of the mechanism of fructose-induced hypertriglyceridemia in the rat. Metabolism, 311: 1077-1083.

9. Hwang I-S, Huang W-C, Wu J -N, Shian LR \& Reaven GM (1989). Effect of fructoseinduced hypertension on the renin-angiotensin-aldosterone system and atrial natriuretic factor. American J oumal of $\mathrm{Hy}-$ pertension, 2: 424-427.

10. Langford HG (1991). Sodium-potassium interaction in hypertension and hypertensive cardiovascular disease. Hypertension, 17 (Suppl I): I-155-I-157.

11. Reeves PG, Nielsen FH \& Fahey J r GC (1993). AIN-93 purified diets for laboratory rodents: Report of the American Institute of Nutrition ad hoc Writing Committee on the reformulation of the AIN-76 rodent diet. J ournal of Nutrition, 123: 1939-1951.

12. Carvalho CRO, Thirone AC, Gontijo J AR, Velloso LA \& Saad MJ A (1997). Effect of captopril, losartan, and bradykinin on early steps of insulin action. Diabetes, 46: 19501957.

13. Lovenberg $W$ (1987). Techniques for the measurements of blood pressure. Hypertension, 9 (Suppl): 15-16.

14. Frayn K (1993). Insulin resistance and lipid metabolism. Current Opinion in Lipidology, 4: 197-204.

15. Bjorntorp P (1994). Fatty acids, hyperinsulinemia and insulin resistance: which comes first? Current Opinion in Lipidology, 5: 166-174.

16. Storlien LH, Oakes DN, Pan DA, Kusunoki $M \&$ J enkins $A B$ (1993). Syndromes of insulin resistance in the rat: inducement by diet and amelioration with benfluorex. Diabetes, 42: 457-462.

17. Matsui H, Okumura K, Kawakami K, Hibino M, Toki Y \& Ito T (1997). Improved insulin sensitivity by bezafibrate in rats: relationship to fatty acid composition of skeletal muscle triacylglycerol. Diabetes, 46: 348-353.

18. Sigrist-Nelson K \& Hopfer U (1974). A distinct D-fructose transport system in isolated brush border membrane. Biochimica et Biophysica Acta, 367: 247-254.

19. Macrae AR \& Neudörffer TS (1972). Support for the existence of an active transport mechanism of fructose in the rat. Biochimica et Biophysica Acta, 288: 137144.

20. Gracey M, Burke $V \& \&$ Oshin A (1972). Active intestinal transport of D-fructose. Biochimica et Biophysica Acta, 266: 397406.

21. Reiser S (1987). Lipogenesis and blood lipids. In: Reiser S \& Hallfrisch J (Editors), Metabolic Effects of Dietary Fructose. CRC Press, Boca Raton, 83-111.

22. Thorbum $A W$, Storlien $L H$, J enkins $A B$, Khour S \& Kraegen EW (1989). Fructoseinduced in vivo insulin resistance and elevated plasma triglyceride levels in rats. American J ournal of Clinical Nutrition, 49: 1155-1163.

23. Tuovinen CGR \& Bender AE (1975). Some metabolic effects of prolonged feeding of starch, sucrose, fructose and carbohydrate-free diet in the rat. Nutrition and
Metabolism, 19: 161-172.

24. Blakely SR, Hallfrisch J , Reiser S \& Prather ES (1981). Long-term effects of moderate fructose feeding on glucose tolerance parameters in rats. J oumal of Nutrition, 111: 307-314.

25. Sutherland C, O'Brien RM \& Granner DK (1995). Phosphatidylinositol 3-kinase, but not p70/p85 ribosomal S6 protein kinase, is required for the regulation of phosphoenolpyruvate carboxykinase (PEPCK) gene expression by insulin. J oumal of Biological Chemistry, 270: 15501-15506.

26. Mithieux G, Daniele N, Payrastre B \& Zitoum C (1998). Liver microsomal glucose-6-phosphatase is competitively inhibited by the lipid products of phosphatidylinositol 3-kinase. J ournal of Biological Chemistry, 273: 17-19.

27. Van Weeren PC, Bruyn KMT, Vries-Smits AMM, Vanlint J \& Burgering BMTH (1998). Essential role for protein kinase B $(\mathrm{PKB})$ in insulin-induced glycogen synthase kinase 3 inactivation. J ournal of Biological Chemistry, 273: 13150-13156.

28. Navarro-Cid J, Maeso R, Perez-Vizcaino F, Cachofeiro V, Ruilope LM, Tamargo J \& Lahera V (1995). Effects of losartan on blood pressure, metabolic alterations, and vascular reactivity in the fructose-induced hypertensive rat. Hypertension, 26: 10741078

29. limura O, Shimamoto K, Matsuda K, Masuda A, Takizawa H, Higashiura K, Miyazaki Y, Hirata A, Ura N \& Nakagawa $M$ (1995). Effects of angiotensin receptor antagonist and angiotensin converting enzyme inhibitor on insulin sensitivity in fructose-fed hypertensive rats and essential hypertensives. American J oumal of Hypertension, 8: 353-357.

30. Kobayashi R, Nagano M, Nakamura F, Higaki J , Fujioka Y, Ikegami H, Mikami $\mathrm{H}_{\text {, }}$ Kawaguchi N, Onishi S \& Ogihara T (1993). Role of angiotensin II in high-fructose-induced left ventricular hypertrophy in rats. Hypertension, 21: 1051-1055.

31. Kotchen TA, Reddy S \& Zhang HY (1997). Increasing insulin sensitivity lowers blood pressure in the fructose-fed rat. American J ournal of Hypertension, 10: 1020-1026.

32. J ohnson MD, Zhang HY \& Kotchen TA (1993). Sucrose does not raise blood pressure in rats maintained on a low salt intake. Hypertension, 21: 779-785. 